\title{
Impact of age at first calving on reproduction, lactation, postpartum disorders and longevity in Holsteins under Egyptian circumstances
}

\author{
M. M. Hussein, A. A. A. El Agawany* \\ Department of Theriogenology, Faculty of Veterinary Medicine, Beni-Suef University, Beni-Suef \\ 62511, Egypt
}

\begin{abstract}
A retrospective study including reproductive and productive data of 1587 primiparous Holstein cows covering a period of eight years. The reproductive data ( interval to $1^{\text {st }}$ service, service period, days open, number of inseminations per conception and calving interval ) and the productive data ( total milk yield, average daily milk yield and 305 day milk yield) were studied as a function of age at first calving and postpartum disorders. Furthermore, other data including life span longevity, number of parities, the cumulative productive days and the average calving interval were also studied as a function of age at first calving. Cows were classified according to the age at first calving into young age calvers ( $<24$ months), mid age calvers $(\geq 24-28$ months) and old age calvers ( $>28$ months). The obtained data were statistically analyzed, tabulated and discussed. The overall mean age at first calving was 26.68 months in Holstein cows under Egyptian circumstances. Most of first calving $(90 \%)$ were recorded in cows less than 30 month of age. The results indicated that, the young age calvers tend to have prolonged interval to $1^{\text {st }}$ service, days open and calving interval and the reverse was correct in old age calvers. The postpartum disorders had significantly detrimental effects on the reproductive performance among the different age groups. Young age calvers had a higher incidence of postpartum disorders than those of mid - age calvers and much higher than had the old age group. The postpartum disorders were associated with high milk production specially in mid and old age calvers which may indicate the high predisposition of superior producer cows to postpartum disorders. Life span, longevity, number of parities and the cumulative production days were found to be increased as a function of age at first calving. Meanwhile, the average calving interval of the young age calvers was longer than the other two age groups. Finally, it was recommended to avoid insemination of maiden Holstein heifers less than 17 month of age specially those having superior productive traits.
\end{abstract}

The productive life of a dairy cow is an indication of her utility and is influenced by her age at first calving, calving intervals, length of each lactation, and success in surviving to lactation (Hare et al., 2006). Age at first calving is an environmental factor influencing milk yield and milk composition (Pirlo et al., 2000), with low heritability trait (Edriss and Vatan-khah, 1998).

Age at first calving (AFC) has a significant influence on the total cost of raising dairy replacements with older calving heifers being more expensive to rise than younger (Ojango and Pollott, 2001; Tozer and Heinrichs, 2001).

* Corresponding author. Tel.: +20 2322066;

fax: +20822327982 .

E-mail address: agawany@bsu.edu.eg

Aly Ahmed El Agawany
Furthermore, reducing age at first calving can also improve the profitability of the enterprise by increasing lifetime milk production and milk production per year of herd life (Lin et al., 1988). Age at first calving can be reduced by a combination of increasing prepubertal average daily gain and decreasing age at breeding ( Van Amburgh et al., 1998; Ojango and Pollott, 2001 and Radcliff et al., 2000) or by reducing age at breeding alone (Lin et al., 1986; Ettema and Santos, 2004). Heinrichs (1993) and Hoffman (1997) suggested that optimum age at first calving for Holsteins for maximum profit should be 23 to 24 months of age. The data on the effect of reduced age at first calving on first lactation milk yield by US Holsteins is variable. Some have observed no effect (Gardner et al., 1988) while others have observed a negative effect (Lin et al., 1986; Van Amburgh et al., 1998; Radcliff et al., 2000; Ettema and Santos, 2004). Milk 
yield in second and greater lactations has consistently been unaffected by reduced age at first calving (Lin et al., 1986; Gardner et al., 1988; Van Amburgh et al., 1998). In fact, Lin et al., (1988) observed greater lifetime production and greater production per year of herd life in heifers that freshened at 23 vs. 26 months of age. The pool of recent literature (Gardner et al., 1988; Lin et al., 1988; Hoffman et al.,1996; BarPeled et al., 1997; Van Amburgh et al., 1998; Radcliff et al., 2000; Vicini et al., 2003a; Ettema and Santos; 2004) suggested that a reduction in age at first calving from an average of 24.7 to 21.9 months results in an approximate $4.8 \%$ reduction in first lactation milk yield. In these studies, age at first calving was reduced by either reducing age at breeding alone or in combination with increasing prepubertal average daily gain.

Longevity is a trait of increasing importance in dairy cow breeding and selection. Longevity has its important economic value within dairy cattle breeding schemes (Essl, 1998). In the literature, various definitions of longevity and many different methods of analysis are used, and results differ greatly. Dekkers (1993); Vollema, (1998); Dakay, et al., (2006) defined the longevity of cows as the time elapsing between first calving and culling .

In most developed countries, ages at first calving are reported by national herd-book societies and the data are compiled in the yearbook annually for publishing. Meanwhile in Egypt we have no complete authorized data about age at first calving.

The objectives of this study were to determine the impact of age at first calving in Holstein heifers on reproduction, lactation and the incidence of postpartum disorders at first lactation. Moreover, its impact on the longevity in a large commercial dairy farm under Egyptian management circumstances.

\section{Materials and Methods}

Animals, housing, and feeding. Eight years records of primiparous Holstein heifers were retrospectively studied $(n=1587)$. These animals were belonging to LS Commercial dairy farm located at kilo,55 Alexandria -Cairo Desert Way in Al Nobaria region, El Behera Governorate, Egypt.

Nulliparous heifers were housed in open corrals distributed according to body weight and age. Nulliparous heifers were fed 2 diets, one for the period between weaning and 12 month of age, and a second diet for the period between breeding (13 month) and 255 day pregnant. The total mixed ration (TMR) was formulated according to NRC, $(1989 ; 2001)$. When heifers were 252 to 258 day pregnant, they were moved to a prepartum pen where they were fed a TMR higher in energy and protein. After calving and during the entire 305-day lactations, primiparous cows were housed separately from multiparous cows in an open yard system. All primiparous cows received the same TMR throughout the entire lactation formulated to meet the nutrient requirements for lactating Holstein cows. Diets were offered twice daily, for an expected 3\% refusal of the total amount offered daily. Cows were milked three times a day.

Primiparous cows were retrospectively assigned to 1 of 3 groups based on age at first calving into three groups. Group 1 including primiparous heifers calved for the first time $<24$ months, group 2 including primiparous heifers calved for the first time $\geq 24-28$ months and group three including those calved for the first time $>28$ months. This grouping strategy was used because age at first calving is usually considered economically optimum when heifers calve at 24 months of age (Heinrichs, 1993).

Reproductive Management of Nulliparous Heifers. AI was performed for heifers according to body weight and withers height. Heifers were inseminated when reached $360-380 \mathrm{Kg}$ body weight and wither height of 140- $145 \mathrm{~cm}$. Heifers were inseminated upon detected estrus based on visual observation. AI was conducted by the Veterinarians by using frozen semen with high calving ease. Pregnancy was diagnosed by palpation per rectum in all animals between 35 and 48 day after AI. Nonpregnant heifers at palpation per rectum were re-checked for pregnancy after 15 days and negative animals for pregnancy was injected with PGF2á upon detection of a CL.

Reproductive Management of Postpartum Primiparous Cows. After the voluntary waiting period (50-60 days postpartum), all lactating cows were observed for estrus three times per day and the estrous cows were inseminated .The anestrous cows were treated by $\mathrm{PGF}_{2 \dot{\alpha}}$ or a timed AI protocol (Ov-synch program) . Pregnancy diagnosis was performed by rectal palpation between 35 and $48 \mathrm{~d}$ after $\mathrm{AI}$, and pregnant cows had their pregnancy reconfirmed immediately at 160 to 180 day pregnant. Non-pregnant cows enrolled in a timed AI protocol for reinsemination.

Monitoring of reproduction. Individual records of animals included birth date, date of calvings, 
date and number of inseminations, date of last or fertile insemination, results of pregnancy diagnosis and postpartum examinations. The following reproductive performances were calculated: a) Age at first calving (months), b) Calving to first insemination, c)Service period [ days elapsed from the $1^{\text {st }}$ insemination to the fertile one], d) Days open [days elapsed from calving to the fertile insemination], e) Number of inseminations per conception, f)Calving interval (days) and g) Incidence of postpartum disorders (\%).

Monitoring of productivity. An individual dairy record was obtained on lifetime of each cow. the productive indices included:a) Average daily milk yield (ADMY) in $\mathrm{kg}, \mathrm{b}) 305$ day milk yield $(\mathrm{kg}), \mathrm{c})$ Total milk production per lactation (kg).

Monitoring lifetime indices. Age or lifespan, time elapsed from date of birth to removal (months); a) Longevity, time elapsed from first calving to removal date (months), b) Number of parities, c) Average calving intervals (days), d) Life time productive days [cumulative days of milk production].

Monitoring Health Events in Postpartum Cows. Health was monitored daily during the first 2 to 3 weeks postpartum. Cows with signs of illness, rectal temperatures were taken. Cows with rectal temperature above $39.5^{\circ} \mathrm{C}$ were considered as febrile and treated according to protocols established by the herd veterinarian. Fetal membranes retained $>24$ hours were diagnosed by farm personnel. Diagnosis of left displacement of abomasum (LDA) was based on clinical signs. Cows diagnosed with LDA were treated by surgical correction. Supportive therapy with propylene glycol or calcium and antibiotics was used as needed. All cows were examined for clinical mastitis by herd personnel during milking, 3 times daily. Cystic ovarian disease was diagnosed by rectal palpation and acute postpartum metritis was diagnosed by the presence of systemic reaction with abnormal vaginal discharge within the first ten days after parturition.

Statistical Analyses. A total of 1587 heifers were included in the data analyses. Only cows that had been diagnosed as pregnant were included in the analysis of reproductive performance and lactation performance was analyzed only for cows of 305 day milk yield with the SAS (1996) program. Data of life span and longevity were calculated only for culled cows. Cows culled during outbreak of foot and moth disease, lumpy skin disease and three day sickness during the years 2001 and 2006 were discarded from the analysis. The incidence of postpartum disorders was calculated by regarding any affected cows with one or more disorders as positive $(100 \%)$ and the non affected cow as negative $(00 \%)$. The incidence was statistically calculated as overall mean \pm SEM for each age group according to Thirkettle (1985).

\section{Results}

As shown in fig 1 , by the twenty two month of age about $20 \%$ of the first calving were recorded, which increased to $60 \%$ by the twenty six month of age; to $90 \%$ by the thirty month of age and about $100 \%$ by the thirty four month of age.

In general, cows gave their first calving under 24 months of age had a tendency to delay the subsequent calving. Meanwhile, those gave their first calving at or after 28 months of age tend to have a shorter calving interval (table 1, fig., 2). Young aged cows at first calving $(<24$ months) had long days open in comparison with mid aged calvers (24-28 months) and comparatively longer days open than the late calver cows ( $\geq 28$ months). Furthermore, the number of inseminations per conception did not influenced by the age at first calving. Cows gave their calving between 24 and 28 months of age had a shorter interval to first insemination in comparison with the other two groups. However, late calver cows ( $\geq 28$ months) had significantly shorter service periods.

As shown in table 2, the incidence of postpartum disorders were very high $(70.33 \%)$ in young age calvers, moderate in the mid age calvers $(57.98 \%)$ and low in the old age calvers $(40.15 \%)$.

The postpartum disorders had significantly detrimental effects on the reproductive performance among the different age groups of Holstein dairy cows. However, the adverse effects on the mid age calver cows (24-28 months) were comparatively lower than those of the other age groups (table, 2; fig 3).

A highly significant regressive correlation was recorded between the age at first calving and the incidence of postpartum disorders $(\mathrm{r}=$ 0.9925 at $\mathrm{p}<0.001$ ). Calving intervals as well as days open were regressively correlated with the age at first calving (table 5). Moreover, the interval to first insemination was negatively correlated with the age at first calving in young age calvers $(<26$ months $)$, the reverse was 

Table 1: Reproductive performance of Holstein dairy cows as a function of age at first calving (Means \pm SE).

\begin{tabular}{|c|c|c|c|c|c|c|c|}
\hline \multirow[b]{2}{*}{ Age (gps) } & \multicolumn{7}{|c|}{ Parameters } \\
\hline & (N) & $\begin{array}{c}\text { AFC } \\
\text { (month) }\end{array}$ & $\begin{array}{l}\text { Interval to } 1^{\text {st }} \\
\text { insemination } \\
\text { (days) }\end{array}$ & $\begin{array}{l}\text { Service period } \\
\text { (days) }\end{array}$ & $\begin{array}{l}\text { Days open } \\
\text { (days) }\end{array}$ & $\mathrm{S} / \mathrm{C}$ & $\begin{array}{c}\text { Calving interval } \\
\text { (days) }\end{array}$ \\
\hline$<24$ months & 300 & $21.83 \pm 0.11$ & $106.17 \pm 4.12^{b}$ & $111.83 \pm 7.22$ & $219.67 \pm 7.63^{b}$ & $2.99 \pm 0.11$ & $499.7 \pm 7.63^{b}$ \\
\hline$\geq 24-28$ months & 764 & $25.97 \pm 0.04$ & $95.10 \pm 1.98^{\mathrm{a}}$ & $113.04 \pm 6.79$ & $208.14 \pm 6.99^{a b}$ & $3.03 \pm 0.07$ & $488.14 \pm 6.99^{a b}$ \\
\hline$>28$ months & 523 & $30.50 \pm 0.08$ & $100.13 \pm 2.80^{a b}$ & $94.82 \pm 5.08$ & $194.95 \pm 5.36^{\mathrm{a}}$ & $2.98 \pm 0.08$ & $474.90 \pm 5.30^{a}$ \\
\hline Overall mean & 1587 & $26.68 \pm 0.07$ & $98.85 \pm 0.10$ & $106.80 \pm 0.21$ & $205.97 \pm 0.22$ & $3.00 \pm 0.01$ & $485.96 \pm 0.22$ \\
\hline
\end{tabular}

$\mathrm{S} / \mathrm{C}=$ number of inseminations per conception

Means within the same column with different alphabetical superscript are significantly different at $\mathrm{P}<0.05$.

Table 2: Reproductive performance of Holstein dairy cows as a function of age at first calving and post partum disorders (Means \pm SE).

\begin{tabular}{|c|c|c|c|c|c|c|c|}
\hline \multirow[b]{2}{*}{ Age (gps) } & \multicolumn{7}{|c|}{ Parameters } \\
\hline & AFC & $\begin{array}{c}\text { Incidence of } \\
\text { postpartum disorders } \\
(\%)\end{array}$ & $\begin{array}{l}\begin{array}{l}\text { Interval to } 1^{\text {st }} \\
\text { insemination } \\
\text { (days) }\end{array} \\
\end{array}$ & $\begin{array}{l}\text { Service period } \\
\quad \text { (days) }\end{array}$ & $\begin{array}{l}\text { Days open } \\
\text { (days) }\end{array}$ & $\mathbf{S} / \mathbf{C}$ & $\begin{array}{c}\text { Calving interval } \\
\text { (days) }\end{array}$ \\
\hline \multirow[b]{2}{*}{$<24$ months } & $21.88 \pm 0.19$ & $\begin{array}{c}* 89 / 300 \\
(29.67 \pm 2.64)\end{array}$ & $87.80 \pm 4.80^{a}$ & $67.11 \pm 9.05^{\mathrm{a}}$ & $158.15 \pm 9.94^{a}$ & $2.66 \pm 0.20^{a}$ & $438.2 \pm 9.94^{\mathrm{a}}$ \\
\hline & $21.82 \pm 0.13$ & $\begin{array}{c}* * 211 / 300 \\
(70.33 \pm 2.64)\end{array}$ & $113.70 \pm 5.41^{b}$ & $130.40 \pm 9.2^{b}$ & $245.13 \pm 9.45^{b c}$ & $3.13 \pm 0.14^{a b}$ & $525.13 \pm 9.45^{b}$ \\
\hline \multirow{3}{*}{$\geq 24-28$ months } & $26.5 \pm 0.06$ & $\begin{array}{c}* 321 / 764 \\
(42.02 \pm 1.79)\end{array}$ & $90.43 \pm 3.21^{a}$ & $93.32 \pm 13.86^{a}$ & $183.76 \pm 14.16^{a}$ & $2.79 \pm 0.10^{a}$ & $463.76 \pm 14.16^{a}$ \\
\hline & $25.76 \pm 0.05$ & $\begin{array}{c}* * 443 / 764 \\
(57.98 \pm 1.79)\end{array}$ & $98.60 \pm 2.50^{a b}$ & $127.47 \pm 5.99^{b}$ & $226.05 \pm 6.24^{b}$ & $3.19 \pm 0.09^{b}$ & $506.05 \pm 6.24^{b}$ \\
\hline & $\mathbf{3 0 . 5 7} \pm \mathbf{0 . 1 0}$ & $\begin{array}{c}* 313 / 523 \\
(59.85 \pm 2.15)\end{array}$ & $93.24 \pm 2.69^{a}$ & $78.88 \pm 4.40^{a}$ & $172.13 \pm 4.64^{a}$ & $2.99 \pm 0.10^{a b}$ & $452.13 \pm 2.69^{a}$ \\
\hline$>28$ months & $30.96 \pm 0.13$ & $\begin{array}{c}* * 210 / 523 \\
(40.15 \pm 2.15)^{a}\end{array}$ & $108.15 \pm 5.20^{b}$ & $152.5 \pm 11.19^{b}$ & $260.7 \pm 12.00^{c}$ & $3.74 \pm 0.17^{\mathrm{c}}$ & $540.62 \pm 12.09^{b}$ \\
\hline
\end{tabular}

* Cows without post partum disorders $\quad *$ * cows with post partum disorders $\mathrm{S} / \mathrm{C}=$ number of inseminations per conception

* Post partum disorders including RFM, postpartum metritis, cystic ovarian disease, abomasal displacement and acute mastitis

Means within the same column with different alphabetical superscript are significantly different at $\mathrm{P}<0.05$. 

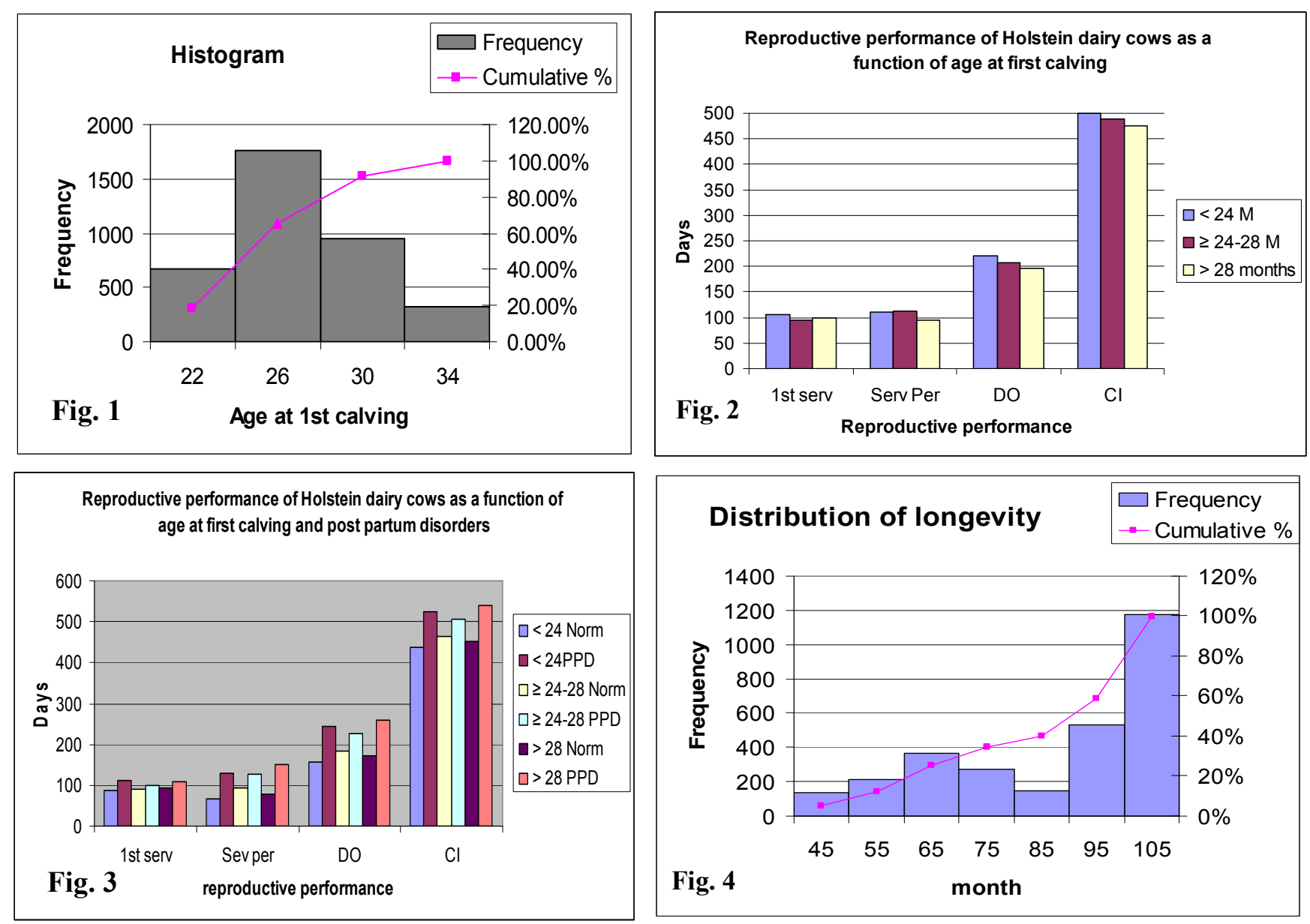

Table 3: Productive performance of Holstein dairy cows as a function of age at first calving (Means \pm SE).

\begin{tabular}{cccccc}
\hline \multirow{2}{*}{ Age (gps) } & \multicolumn{5}{c}{ Parameters } \\
\cline { 2 - 6 } & (N) & AFC & Total milk yield (Kg) & ADMY & 305 days milk yield (Kg) \\
\hline$<24$ months & $(143)$ & $21.52 \pm 0.16$ & $9934 \pm 274$ & $\mathbf{2 4 . 8 9} \pm 0.50^{\text {ab }}$ & $7593 \pm 160^{\text {ab }}$ \\
$\geq 24-28$ months & $(421)$ & $26.08 \pm 0.05$ & $10287 \pm 164$ & $26.22 \pm 0.30^{\text {b }}$ & $7998 \pm 101^{\text {b }}$ \\
$>28$ months & $(376)$ & $30.46 \pm 0.09$ & $9927 \pm 191$ & $23.91 \pm 0.30^{\text {a }}$ & $7292 \pm 98^{\text {a }}$ \\
\hline
\end{tabular}

ADMY = average daily milk yield

Means within the same column with different alphabetical superscript are significantly different at $\mathrm{P}<0.05$ 
Table 4: Productive performance of Holstein dairy cows as a function of age at first calving and post partum disorders (Means $\pm \mathrm{SE}$ ).

\begin{tabular}{|c|c|c|c|c|c|}
\hline \multirow[b]{2}{*}{ Age (gps) } & \multicolumn{5}{|c|}{ Parameters } \\
\hline & AFC & $\begin{array}{c}\text { Incidence of } \\
\text { postpartum } \\
\text { disorders (\%) }\end{array}$ & $\begin{array}{l}\text { Total milk } \\
\text { yield (Kg) }\end{array}$ & $\begin{array}{c}\text { ADMY } \\
\text { (Kg) }\end{array}$ & $\begin{array}{c}305 \text { days } \\
\text { milk yield }(\mathrm{Kg})\end{array}$ \\
\hline \multirow{2}{*}{$<24$ months } & $21.28 \pm 0.29$ & $\begin{array}{c}* 43 / 142 \\
(30.28 \pm 3.86)\end{array}$ & $8918 \pm 371^{a}$ & $26.21 \pm 0.96^{b c}$ & $7994 \pm 294^{b c}$ \\
\hline & $21.60 \pm 0.20$ & $\begin{array}{c}{ }^{* *} 99 / 142 \\
(69.72 \pm 3.86)^{c}\end{array}$ & $10453 \pm 344^{b}$ & $24.49 \pm 0.6^{a b}$ & $7471 \pm 184^{a b}$ \\
\hline \multirow{2}{*}{$\geq 24-28$ months } & $26.38 \pm 0.07$ & $\begin{array}{c}* 209 / 453 \\
(46.13 \pm 2.34)\end{array}$ & $9266 \pm 201^{a}$ & $24.75 \pm 0.51^{b}$ & $7550 \pm 157^{b}$ \\
\hline & $25.84 \pm 0.06$ & $\begin{array}{c}* * 244 / 453 \\
(53.87 \pm 2.34)^{b}\end{array}$ & $11022 \pm 242^{b c}$ & $26.89 \pm 0.43^{c}$ & $8204 \pm 133^{c}$ \\
\hline \multirow{2}{*}{$>28$ months } & $30.51 \pm 0.11$ & $\begin{array}{c}* 251 / 376 \\
(66.75 \pm 2.43)\end{array}$ & $8951 \pm 140^{a}$ & $23.23 \pm 0.38^{a}$ & $7087 \pm 117^{a}$ \\
\hline & $30.36 \pm 0.16$ & $\begin{array}{c}* * 125 / 376 \\
(33.25 \pm 2.43)^{a}\end{array}$ & $11887 \pm 456^{c}$ & $25.26 \pm 0.56^{b c}$ & $7705 \pm 172^{b c}$ \\
\hline
\end{tabular}

*Cows without post partum disorders $\quad{ }^{* *}$ cows with post partum disorders

* Post partum disorders including RFM, postpartum metritis, cystic ovarian disease, abomasal displacement and acute mastitis

Means within the same column with different alphabetical superscript are significantly different at $\mathrm{P}<0.05$

Table 5: The coefficient of correlations between age at first calving and some reproductive and productive performances.

Parameters

Age at first calving

Interval to first insemination

Up to 26 months

$>26$ months

Days open

$-0.8309$

$+0.8485$

No. of insemination per conception

$-0.7601$

$-0.7598$

Calving interval

$+0.8265$

$-0.8371$

305 days milk production

$-0.9296$

$-0.9365$

$+0.9803$

$-0.9854$

All coefficients of correlations are highly significant at $\mathrm{P}<0.001$.

Table 6: longevity of Holstein cows in relation to age at first calving.

\section{Parameters}

\begin{tabular}{cccccccc} 
Age (gps) & No & $\begin{array}{c}\text { AFC } \\
\text { (month) }\end{array}$ & $\begin{array}{c}\text { Longevity } \\
\text { (month) }\end{array}$ & $\begin{array}{c}\text { Age } \\
\text { (month) }\end{array}$ & $\begin{array}{c}\text { Number } \\
\text { of } \\
\text { Parities }\end{array}$ & ACI (day) & $\begin{array}{c}\text { productive } \\
\text { days }\end{array}$ \\
\hline$<24$ months & 162 & $22.21 \pm 0.14^{\mathrm{a}}$ & $71.7 \pm 1.37^{\mathrm{a}}$ & $\mathbf{9 3 . 2 8} \pm 0.68^{\mathrm{a}}$ & $\mathbf{3 . 0 6}_{0.00^{\mathrm{a}}}$ & $478.14 \pm 8.53^{\mathrm{b}}$ & $1231 \pm 35.3^{\mathrm{a}}$ \\
$\geq 24-28$ months & 443 & $26.04 \pm 0.05^{\mathrm{b}}$ & $77.3 \pm 1.24^{\mathrm{b}}$ & $103.33 \pm 1.25^{\mathrm{b}}$ & $3.28 \pm 0.06^{\mathrm{ab}}$ & $456.15 \pm 3.98^{\mathrm{a}}$ & $1274 \pm 25.4^{\mathrm{a}}$ \\
$>28$ months & 370 & $30.54 \pm 0.09^{\mathrm{c}}$ & $95.13 \pm 0.88^{\mathrm{c}}$ & $125.67 \pm 0.88^{\mathrm{c}}$ & $3.60 \pm 0.08^{\mathrm{b}}$ & $460.77 \pm 4.40^{\mathrm{ab}}$ & $1404 \pm 31.6^{\mathrm{b}}$ \\
& & & & & & & \\
Overall mean & 975 & $27.11 \pm 0.10$ & $\mathbf{8 2 . 1 3} \pm 0.77$ & $109.25 \pm 0.83$ & $3.36 \pm 0.04$ & $461.56 \pm 2.85$ & $1316 \pm 17.7$ \\
\hline
\end{tabular}

$\mathrm{AFC}=$ age at first calving $\mathrm{ACI}=$ average calving interval

Means within the same column with different alphabetical superscript are significantly different at $\mathrm{P}<0.05$. 
correct thereafter (table, 5).

As shown in table 3, a significantly higher value of 305 days milk was recorded for the mid age group ( $\geq 24-28$ months) in comparison with the old age group ( $>28$ months). Meanwhile, an intermediate value of 305 days milk was recorded for the young age group ( $<24$ months).

Regarding the interrelationship between postpartum disorders and 305 days milk yield, significantly higher values of milk yield were recorded for animals with postpartum disorders in mid ( $\geq 24-28$ months ) and old age group ( $>$ 28 months). Meanwhile, 305 days milk yield was insignificantly decreased in cows of young age group ( $<24$ months) as shown in table 4 .

Although progressive correlation was demonstrated between 305 days milk production and the age at first calving up to $26^{\text {th }}$ month, it was followed by regressive correlation in old calver cows (table 5).

As shown in table 6 and fig., 4, life span, longevity, number of parities and the cumulative production days have been increased as a function of age at first calving. Meanwhile the average calving interval was longer in young age calver $(<24$ months) than those in mid and old calver (24-28 and $>28$ months, respectively).

\section{Discussion}

The overall mean age at first calving in the current study (26.68 \pm 0.07 months) was nearly equal to the estimated mean of 26.84 months in Iran (Nilforooshan and Edriss , 2004), and was greater than the estimated mean of 25.9 months in the United States (Heinrichs et al., 1994) and the estimate of 26 months in Italy (Pirlo, 1997). Meanwhile, it was less than the estimated mean of 28.6 months in Spain (Perez et al., 1999) and 29.76 months in Sudan (Gader et al., 2007). These variations may be attributed to nutritional, climatic, and / or managemental conditions.

In general, the current study revealed prolonged day's open and calving interval in the first calf heifers which are consistent with Aly et al., (2000) in Egypt and Gader et al., (2007) in Sudan. Meanwhile, these values were higher than those reported by Fulkerson et al., (2001) in Australia, Hare et al., (2006) and Heins et al., (2006) in USA. This may be attributed to the negative energy balance of young cows after calving which has been magnified by genetic selection for increased productivity in Egypt.

The significantly higher values reported for the interval to first service, days open and calving interval in young age group in the current study are consistent with Butler and
Smith, (1989); Bell, (1995). Moreover, Harrison et al., (1990) also found a delay of 23 days to onset of first estrus, while Bonczek et al., 1992) found an 11 day delay in time to first service in high producing Friesian cows of young age selected for high milk production. Milk yield and growth have the priority over reproduction in high producing first calf heifers with large energy requirements at the onset of lactation. These results in a severe negative energy balance during the early lactation period (Butler and Smith, 1989 and Bell, 1995), which may adversely impact postpartum health and fertility (Lucy et al.,1991; de Vries et al., 1999).

Our findings of the high incidence of postpartum disorders in association with young age calvers are in agreement with those reported by Erb and Martin (1980); Markusfeld (1987); Gröhn and Rajala-Schultz (2000); Yeon Lee and Hwa Kim (2006). Metabolic disorders in young age calvers are positively correlated with body weight at freshening of first calf heifers and influenced by increased milk yield (Fleischer et al., 2001). Moreover, with a severe loss of body weight a delayed recovery of body condition during early lactation which resulting in detrimental effects on the fertility parameters (Kim and Suh, 2003).

The current results revealed that, postpartum disorders had significantly detrimental effects on the reproductive performance among the different age groups of Holstein dairy cows. However, the adverse effects on the mid age calver cows (24-28 months) were comparatively lower than those of the other age groups. These results are consistent with Bagnato and Oltenacu, (1993); Emanuelson and Oltenacu, (1998); Gröhn and Rajala-Schultz, (2000); Roxstrom et al., (2001); Maizona et al., (2004). In general, the literatures show that reproductive performances were negatively affected by diseases such as dystocia, retained placenta, or cystic ovaries (Fourichon et al., 2000). To estimate the effects of diseases on reproductive traits, different statistical approaches have been used, including linear models (Emanuelson and Oltenacu, 1998; Kinsel and Etherington, 1998; Oltenacu et al., 1990; Ouweltjes et al., 1996) and logistic regression (Gröhn et al., 1990). Moreover, survival analysis was used to assess the effects of diseases on days open (Eicker et al., 1996; Suriyasathaporn et al., 1998) and days from calving to first insemination (Eicker et al., 1996; Suriyasathaporn et al., 1998). These studies reported that metritis, lameness, cystic 
ovaries, and retained placenta negatively affected reproductive performance. Among these studies, only Suriyasathaporn et al., (1998) considered diseases (genital infection and cystic ovaries) as time-dependent covariates. Survival analysis allows for a more appropriate management of censored data and time-dependent covariates (Gröhn et al., 1997; Kalbfleisch and Prentice, 2002), which are very common in the study of variables such as days open, days to first insemination, and service period.

Our results revealed that, first lactation milk yield was higher by increasing age at first calving up to 28 months, but with delayed onset of first lactations (>28 month) lower values of milk yield were obtained.

A slight negative phenotypic correlation was reported between age at first calving and firstlactation milk yield (Edriss and Vatan-khah, 1998; Nilforooshan and Edriss, 2004). These results are inconsistent with other reports (Moore et al., 1991; Pirlo et al., 2000) that reported positive effects of delayed age at first calving on milk yield. In contrast, our results are consistent with those of Bewley et al., (2001), who reported a negative effect of increasing age at first calving on milk yield. Moreover, Gardner et al., (1988); Losinger and Heinrichs (1996); Mourits et al., (1997) demonstrated production to be lower when age at first calving is greater than 27 months and concluded that time to breed heifers should be based on body weight rather than age. We could not consider the effect of body weight on yield traits because no information was available on the population basis. A negative effect of early calving on milk yield was obtained in our study may be due to insufficiently developed heifers. But the decrease in milk yield in late-bred heifers may be due to other factors correlated with age. In addition, it seems that mammary development was diminished in late-bred heifers or the mammary glands were replaced by adipose tissues.

Our study revealed significantly higher values of 305 days milk yield were recorded for cows with postpartum disorders in mid and old age groups and the reverse was correct in cows of young age group. These results agreed with that reported by VanRaden, (2002) and Miglior et al., (2005). The association between postpartum disorders with high milk production specially in mid and old age calvers may insuring the high predisposition of superior producer cows to postpartum disorders
(Veerkamp et al., 2001; Haile-Mariam et al., 2003; Kadarmideen et al., 2003).

For many years, most selection indices worldwide focused on increasing milk production (Miglior et al., 2005). In Egypt selection indices were based on improving milk yield and gradually shifted toward improving fat and protein yield. Several studies have shown that selection for production alone causes negative effects on udder health (Heringstad et al., 2003) and reproductive performance (Veerkamp et al., 2001; Haile-Mariam et al., 2003; Kadarmideen et al., 2003).

On average, cows in this study had $1316 \pm$ 17.7 days of productive life during $3.36 \pm 0.04$ parities, which is nearly to $1236 \pm 593$ days of productive life and $3.3 \pm 1.5$ parities obtained in Spain (Perez et al., 1999) but higher than $30.1 \pm$ 20.7 months of productive life during $2.6 \pm 1.5$ lactations in Iran (Nilforooshan and Edriss, 2004). The productive days have been increased as a function of age at first calving; these are consistent with Finch, (1990) and Strandberg (1997) who reported a slight increase in length of productive life with increased age of first calving up to 30 months. Meanwhile our results were inconsistent with Perez et al., (1999) and Nilforooshan and Edriss, (2004). Studies in dairy cattle on longevity generally suffer from the lack of a suitable character to measure the degree of maturity (Essl, 1998) . Some evidence for an antagonistic relation between high first lactation milk yield and longevity is given by Essl, (1998) and Solkner (1989). The significantly lower values of longevity, life span and productive days in the young age group in the current study may be referred to the significantly higher incidences of postpartum disorders in young and mid age groups in comparison with the old age group. These results agreed with Strandberg and Hakansson, (1994) who reported that, early maturing animals have, on average, fewer trouble-free reproductive cycles than latematuring ones.

\section{Conclusion}

Finally it was recommended to avoid insemination of maiden Holstein heifers less than 17 month of age specially those having superior productivity traits. A combined feeding and breeding management program of maiden Holstein heifers is necessary for optimal productive and reproductive performance.

\section{References}

Aly, H. M.; El-Banna, M. K. and Arafa, S. A. ( 2000 ) : 
Factors affecting calving interval, days open and gestation length in Friesian cows. Alex. J. Agri. Res., 45: 123-132 Bagnato, A. and Oltenacu, P. A. (1993): Genetic study of fertility traits and production in different parities in Italian Friesian cattle. J. Anim. Breed. Genet., 110: 126-134.

Bar-Peled, U.; Robinzon, B.; Maltz, E.; Tagari, H.; Folman, Y.; Bruckental, I.; Voet, H.; Gacitua, H. and Lehrer, A. R. (1997): Increased weight gain and effects on production parameters of Holstein heifer calves that were allowed to suckle from birth to six weeks of age. J. Dairy Sci., 80: 2523-2528.

Bell, A. W. (1995): Regulation of organic nutrient metabolism during transition from late pregnancy to early lactation. J. Anim. Sci, 73: 2804-2819.

Bewley, J.; Palmer, R. W. and Jackson-Smith, D. B. (2001): Modeling milk production and labor efficiency in modernized Wisconsin dairy herds. J. Dairy Sci., 84:705716 .

Bonczek, R. R.; Richardson, D. O. and Moore, E. D. (1992): Correlated responses in reproduction accompanying selection for milk yield in Jerseys. J. Dairy Sci., 75:11541160.

Butler, W. R. and Smith, R. D. (1989): Interrelationships between energy balance and postpartum reproductive function in dairy cattle. J. Dairy Sci., 72: 767-783.

de Vries, M. J.; van der Beek, S.; Kaal-Lansbergen, L. M.; Ouweltjes, W.; Wilmink, J. B. (1999): Modeling of energy balance in early lactation and the effect of energy deficits in early lactation on first detected estrus postpartum in dairy cows. J. Dairy Sci., 82: 1927-1934.

Dakay, I.; Marton, D.; Keller, K.; Fordos, A.; Torok, M. and Szabo F. (2006): Study on the age at first calving and the longevity of beef cows. J. Central Europ. Agricult., (3):377-387.

Dekkers, J. C. M. (1993): Teoretical basis for genetic parameters of herd life and efects on response of selection. J. Dairy Sci., 76:1433-1443.

Edriss, M. A. and Vatan-Khah, M. (1998): Genetics and Dairy Cow Breeding. Arkan Press, Iran. 112-135.

Eicker, S. W.; Gröhn, Y. T. and Hertl, J. A. (1996): The association between cumulative milk yield, days open, and days to first breeding in New York Holstein cows. J. Dairy Sci., 79: 235-241.

Emanuelson, U., Oltenacu, P. A. (1998): Incidences and effects of diseases on the performance of Swedish dairy herds stratified by production. J. Dairy Sci., 81:2376-2382. Erb, H. N. and Martin, S. W. (1980): Interrelationships between production and reproductive diseases in Holstein cows. Age and seasonal patterns. J. Dairy Sci., 63:19181924.

Essl, A. (1998): Longevity in dairy cattle breeding: A review. Livest. Prod. Sci., 57: 79-89.

Ettema, J. F. and Santos, J. E. P. (2004): Impact of age at calving on lactation, reproduction, health, and income in first-parity Holsteins on commercial farms. J. Dairy Sci., 87:2730-2742.

Finch, C. E. (1990): Longevity, Senescence, and the Genome. University of Chicago Press, Chicago. 274-275.

Fleischer, P.; Metzner, M.; Beyerbach, M.; Hoedemaker, M. and Klee, W. (2001): The relationship between milk yield and the incidence of some diseases in dairy cows. J. Dairy Sci., 84: 2025-2035.

Fourichon, C.; Seegers, H. and Malher, X. (2000): Effect of disease on reproduction in the dairy cow: a metaanalysis. Theriogenol., 53: 1729-1759.

Fulkerson W. J.; Wilkins, J.; Dobos, R. C.; Hough, G. M.; Goddard, M. E and Davison, T. (2001): Reproductive performance in Holstein-Friesian cows in relation to genetic merit and level of feeding when grazing pasture. Anim. Sci., 73: 397-406.

Gader, A. Z. A.; Ahmed, M. K. A; Musa, L. M. A. and Peters, K. J. (2007): Milk yield and reproductive performance of Friesian cows under Sudan tropical conditions. Archiv fur Tierzucht, 50: 654-663.

Gardner, R. W.; Smith, L. W. and Park, R. L. (1988): Feeding and management of dairy heifers for optimal lifetime productivity. J. Dairy Sci., 71: 996-999.

Gröhn, Y. T. and Rajala-Schultz, P. J. (2000): Epidemiology of reproductive performance in dairy cows. Anim. Repr. Sci., (60-61), 605-614.

Gröhn, Y. T.: Fubini, S. L. and Smith, D. F. (1990): Use of a multiple logistic regression model to determine prognosis of dairy cows with right displacement of the abomasum or abomasal volvulus. Am. J. Vet. Res., 51: 1895-1899.

Gröhn, Y. T.; Ducrocq, V. and Hertl, J. A. (1997): .Modeling the effect of a disease on culling: an illustration of the use of time-dependent covariates for survival analysis. J. Dairy Sci., 80: 1755-1766.

Haile-Mariam, M.; Bowman, P. J. and Goddard, M. E. (2003): Genetic and environmental relationships among calving interval, survival, persistency of milk yield and somatic cell count in dairy cattle. Livest. Prod. Sci., 80:189200.

Hare, E.; Norman, H. D. and Wright, J. R. (2006): Trends in calving ages and calving intervals for dairy cattle breeds in the United States. J. Dairy Sci., 89(1):365-370.

Harrison, R. O.; Ford, S. P.; Young, J. W. and Conley, A. J. (1990): Increased milk production versus reproductive and energy status of high producing dairy cows. J. Dairy Sci., 73: 2749-2758

Heinrichs, A. J. (1993): Raising dairy replacements to meet the needs of the 21st century. J. Dairy Sci., 76:31793187.

Heinrichs, A. J; Wells, S. J; Hurd, G. W.; Hill, H. S. and Dargatz, D. A. (1994): The national dairy heifers evaluation project: A profile of heifer management practices in United States. J. Dairy Sci., 77:1548-1555.

Heins, B. J.; Hansen, L. B. and Seykora, A. J. (2006): Fertility and survival of pure Holsteins versus crossbreds of Holstein with Normande, Montbeliarde, and Scandinavian Red. J. Dairy Sci., 89:4944-51.

Heringstad, B.; Chang, Y. M.; Gianola, D. and Klemetsdal, G. (2003): Genetic analysis of longitudinal trajectory of clinical mastitis in first-lactation Norwegian Cattle. J. Dairy Sci., 86:2676-2683.

Hoffman, P. C. (1997): Optimum body size of Holstein replacement heifers. J. Anim. Sci., 75:836-845.

Hoffman, P. C.; Brehm, N. M.; Price, S. G. and PrillAdams, A. (1996): Effect of accelerated postpubertal growth and early calving on lactation performance of primiparous Holstein heifers. J. Dairy Sci., 79:2024-2031.

Kadarmideen, H. N.; Thompson, R.; Coffey, M. P. and Kossaibati, M. A.(2003): Genetic parameters and evaluations from single- and multiple-trait analysis of dairy cow fertility and milk production. Livest. Prod. Sci., 81:183-195.

Kalbfleisch, J. D. and Prentice, R. L.(2002):The statistical analysis of failure time data, $2^{\text {nd }}$ ed. J. Wiley \& Sons, New York, NY, USA.

Kim, I.H. and Suh, G.H.( 2003): Effect of the amount of body condition loss from the dry to near calving periods on the subsequent body condition change, occurrence of postpartum diseases, metabolic parameters and reproductive 
performance in Holstein dairy cows. Theriogenol., 60, 1445-1456.

Kinsel, M. L. and Etherington, W. G.(1998): Factors affecting reproductive performance in Ontario dairy herds. Theriogenol., 50:1221-1238.

Lin, C. Y.; McAllister, A. J.; Batra, T. R.; Lee, A. J.; Roy, G. L.; Vesely, J. A.; Wauthy, J. M. and Winter, K. A. (1986): Production and reproduction of early and late bred dairy heifers. J. Dairy Sci., 69:760-768.

Lin, C. Y., McAllister, A. J., Batra,T. R Lee, A. J.,Roy, G. L Vesely, J. A. Wauthy, J. M. and Winter, K. A.(1988): Effects of early and late breeding of heifers on multiple lactation performance of dairy cows. J. Dairy Sci., 71:2735-2743.

Losinger, W. C. and Heinrichs, A. J.(1996): Dairy operation management practices and herd milk production. J. Dairy Sci., 79:506-514.

Lucy, M.C.; Staples, C. R.; Michel, F. M. and Thatcher, W.W. (1991): Energy balance and size and number of ovarian follicles detected by ultrasonography in early postpartum dairy cows. J. Dairy Sci., 74:473-482.

Maizona, D. O.; Oltenacua, P. A.; Gröhn, Y.T.; Strawderman, R.L. and Emanuelson, U. (2004): Effects of diseases on reproductive performance in Swedish Red and White dairy cattle. Prev. Vet. Med., 66:113-126.

Markusfeld, O. (1987): Periparturient traits in seven high dairy herds. Incidence rates, association with parity, an interrelationships among traits. J. Dairy Sci., 70:158-166.

Miglior, F. ; Muir, B. L. and Van Doormaal, B. J.(2005): Selection Indices in Holstein Cattle of Various Countries. J. Dairy Sci., 88:1255-1263.

Moore, R. K.; Kennedy, B. W.; Schaeffer, L. R. and Moxley, J. E.(1991): Relationships between age and body weight at calving and production in first lactation Ayrshires and Holsteins. J. Dairy Sci., 74:269-278.

Mourits, M. C. M.; Dijkhuizen, A. A.; Hurine, R. B. M. and Galligan, D. T.(1997): Technical and economic models to support heifer management decisions: basic concepts. J. Dairy Sci., 80:1406-1415.

National Research Council (NRC, 1989): Nutrient Requirements of Dairy Cattle, sixth revised edition. National Academy of Science, Washington, DC, USA, pp. 135-156.

National Research Council (NRC, 2001): Nutrient Requirements of Dairy Cattle, Seventh revised edition. National Academy of Science, Washington, DC, USA, pp. 258-265.

Nilforooshan, M. A. and Edriss, M. A. (2004): Effect of Age at First Calving on Some Productive and Longevity Traits in Iranian Holsteins of the Isfahan Province. J. Dairy Sci., 87:2130-2135.

Ojango, J. M. K. and Pollott, G. E. ( 2001): Genetics of milk yield and fertility traits in Holstein-Friesian cattle on large-scale Kenyan farms. J. Anim. Sci., 79:1742-1750.

Oltenacu, P.A.; Frick, A. and Lindhe, B. (1990): Epidemiological study of several clinical diseases, reproductive performance and culling in primiparous Swedish cattle. Prev. Vet. Med., 9:59-74.

Ouweltjes, W.; Smolders, E.A.A.; Elving, L.; van Eldik, P. and Schukken, Y.H., (1996): Fertility disorders and subsequent fertility in dairy cattle. Livest. Prod. Sci.., 46: 213-220.

Perez, M. A.; Hernandez, D. ; Alenda, R.; Carabano, M. J. and Charfeddine, N. (1999): Genetic analysis of true profit for Spanish dairy cattle. Address www.interbull.slu.se/bulletins/bulletin23/perez.pdf.
Pirlo, G. (1997): Rearing cost of replacement heifer and optimal age at first calving. Suppl. L Informatore Agrario 37:9-12.

Pirlo, G.; Miglior, F. and Speroni, M. (2000): Effect of age at first calving on production traits and on difference between milk yield returns and rearing costs in Italian Holsteins. J. Dairy Sci., 83:603-608.

Radcliff, R. P.; VandeHaar, M. J.; Chapin, L. T.; Pilbeam, T. E.; Beede, D. K.; Stanisiewski, E. P. and Tucker, H. A. (2000): Effects of diet and injection of bovine somatotropin on prepubertal growth and firstlactation milk yields of Holstein cows. J. Dairy Sci., 83:2329.

Roxstrom, A.; Strandberg, E.; Berglund, B.; Emanuelson, U. and Philipsson, J. (2001): Genetic and environmental correlations among female fertility traits, and between the ability to show oestrus and milk production in dairy cattle. Acta Agric. Scand. Sect. A Anim. Sci., 51:192199.

SAS User's Guide (1996) :SAS User Guide. SAS Inst. Inc., Cary, NC.

Solkner, J. (1989): Genetic relationships between level of production in different lactations, rate of maturity and longevity in a dual purpose cattle population. Livest. Prod. Sci., 23:33-45.

Strandberg, E.(1997): Breeding strategies to improve longevity. The 48th Annual Meeting of the European Association of Animal Production, Vienna, Austria, Aug. 25-28, (Mimeo).

Strandberg, E. and Hakansson, L. (1994): Effect of culling on the estimates of genetic correlation between milk yield and length of productive life in dairy cattle. Proceedings of the $5^{\text {th }}$ World Congress on Genetics Applied to Livestock Production, Guelph, Canada 17, pp. $77-80$.

Suriyasathaporn,W.; Nielen, M.; Dieleman, S. J.; Brand, A.; Noordhuizen-Stassen, E.N. and Schukken, Y.H. (1998): A Cox proportional-hazards model with timedependent covariates to evaluate the relationship between body condition score and the risks of first insemination and pregnancy in a high-producing dairy herd. Prev. Vet. Med., 37:159-172.

Thirkettle,G.L. (1985): wheldon's -Business Statistics and Statistical Methods. $9^{\text {th }}$ ed.BcoM(lond) FIS.

Tozer, P. R., and Heinrichs, A. J.(2001): What affects the costs of raising replacement dairy heifers: A multiplecomponent analysis? J. Dairy Sci., 84:1836-1844.

Van Amburgh, M. E.; Galton, D. M.; Bauman, D. E.; Everett, R. W.; Fox, D. G.; Chase, L. E. and Erb, H. N.(1998): Effects of three prepubertal body growth rates on performance of Holstein heifers during first lactation. J. Dairy Sci., 81:527-538.

VanRaden, P. M. (2002): Selection of dairy cattle for lifetime profit. Pages 127-130 in Proc. 7th World Congr. Genet. Appl. Livest. Prod., Montpellier, France

Veerkamp, R. F.; Koenen, E. P. C. and De Jong, G. (2001): Genetic correlations among body condition score, yield, and fertility in first-parity cows estimated by random regression models. J. Dairy Sci., 84:2327-2335.

Vicini, J. L.; Bettis, S. E.; Denham, S. C.; Hintz, R. L.; Holst, J. L.; Plunkett, E. D.; Crooker, B. A.; Weber, W. J.; Chester-Jones, H. and Van Amburgh, M. E. (2003a): Effects of feed management program and POSILAC on prepubertal growth rate of replacement dairy heifers. J. Dairy Sci., 86:(Suppl. 1), 308. (Abstr.)

Vicini, J. L.; Gallian, D. T.; Bettis, S. E.; Bilby, C. R.; 
Denham, S. C.; Hintz, R. L.; Holst, J. L.; Klushmeyer, T. H., Plunkett, E. D.; Crooker, B. A.; Weber, W. J. and Van Amburgh, M. E. (2003b): Effects of prepubertal growth rate and POSILAC treatment of replacement dairy heifers on subsequent milk production and economics. J. Dairy Sci. 86:(Suppl. 1), 307.
Vollema A.R. (1998): Longevity of dairy cows: A review of genetic variances and covariances with conformation. Anim. Breed., 66 (Abstr.), 781-802.

Yeon Lee, J. I. and Hwa Kim, I. I. (2006): Advancing parity is associated with high milk production at the cost of body condition and increased periparturient disorders in dairy herds. J. Vet. Sci., (2):161-166.

\footnotetext{
تأثير العمر عند أول ولادة على التتاسل وإدرار اللبن واعتلالات ما بعد الولادة والعمر الإنتاجي في الأبقار الهولستين في ظل الظروف المصن المصرية

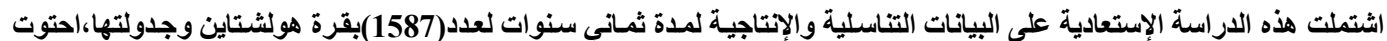

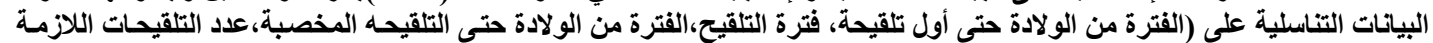

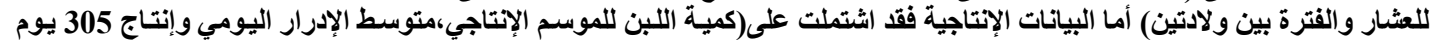

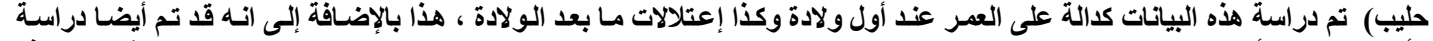

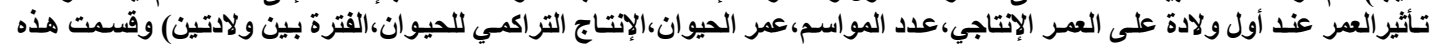

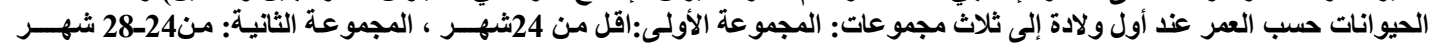

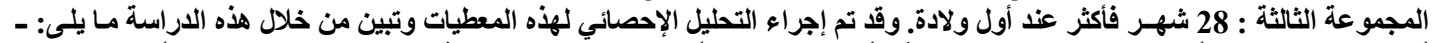

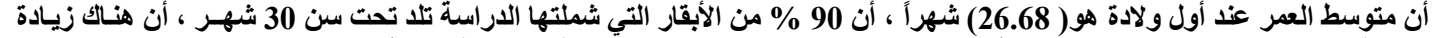

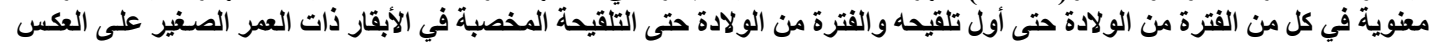

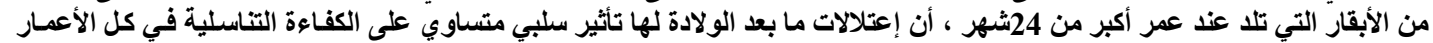

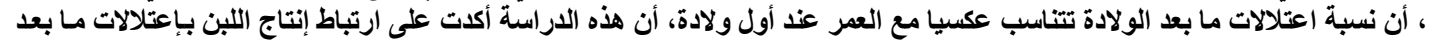

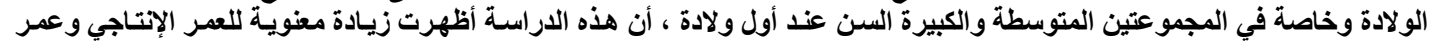

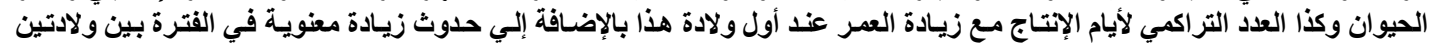

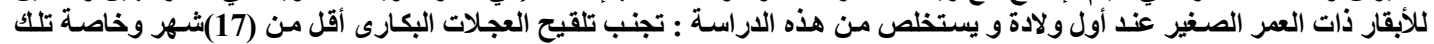
العجلات ذات الصفات الإنتاجية العالية.
} 